\title{
ADDENDUM
}

\section{Editorial Expression of Concern: birinapant sensitizes platinum-resistant carcinomas with high levels of cIAP to carboplatin therapy}

\author{
V. La', R. Fujikawa1 , D. M. Janzen ${ }^{1}$, M. Nunez ${ }^{1}$, L. Bainvoll ${ }^{1}$, L. Hwang ${ }^{2,3,4}$, K. Faull ${ }^{2,3,4}$, G. Lawson ${ }^{5}$ and S. Memarzadeh ${ }^{1,6,7,8,9}$ \\ npj Precision Oncology (2018)2:19; doi:10.1038/s41698-018-0062-1
}

Addendum to: npj Precision Oncology; https://doi.org/10.1038/ s41698-017-0008-z; Published online 03 April 2017.

npj Precision Oncology is publishing an Editorial Expression of Concern on the manuscript 'Birinapant sensitizes platinumresistant carcinomas with high levels of cIAP to carboplatin therapy' from La et al., because of a letter requesting retraction communicated to our journal by S. Memarzadeh, a corresponding author of this manuscript. Concerns have been raised regarding the identity of the cell lines used for the experimental work in Fig. $1 \mathrm{~d}$, and the reporting of the survival of cells presented in Fig. 2a. We understand that this is subject to an ongoing review, and we will continue to monitor the situation and update this statement accordingly. The authors have been informed of this statement. V. La, R. Fujikawa, M. Nunez, L. Bainvoll, L. Hwang, K. Faull and S. Memarzadeh agree with this editorial expression of concern. We were unable to obtain a response from D. M. Janzen and G. Lawson.

\begin{abstract}
cc) Open Access This article is licensed under a Creative Commons Attribution 4.0 International License, which permits use, sharing, adaptation, distribution and reproduction in any medium or format, as long as you give appropriate credit to the original author(s) and the source, provide a link to the Creative Commons license, and indicate if changes were made. The images or other third party material in this article are included in the article's Creative Commons license, unless indicated otherwise in a credit line to the material. If material is not included in the article's Creative Commons license and your intended use is not permitted by statutory regulation or exceeds the permitted use, you will need to obtain permission directly from the copyright holder. To view a copy of this license, visit http://creativecommons. org/licenses/by/4.0/.
\end{abstract}

๑) Springer Nature Ltd 2018

\footnotetext{
${ }^{1}$ Department of Obstetrics and Gynecology, David Geffen School of Medicine, University of California Los Angeles, Los Angeles, CA 90095, USA; ${ }^{2}$ Department of Psychiatry and Biobehavioral Sciences, David Geffen School of Medicine, University of California Los Angeles, Los Angeles, CA 90095, USA; ${ }^{3}$ Pasarow Mass Spectrometry Laboratory, University of California Los Angeles, Los Angeles, CA 90095, USA; ${ }^{4}$ Semel Institute for Neuroscience and Human Behavior, University of California Los Angeles, Los Angeles, CA 90095, USA; ${ }^{5}$ Office of Laboratory Animal Care, University of California Berkeley, Berkeley, CA 94720, USA; ${ }^{6}$ UCLA Eli and Edythe Broad Center of Regenerative Medicine and Stem Cell Research, University of California Los Angeles, Los Angeles, CA 90095, USA; ${ }^{7}$ Molecular Biology Institute, University of California Los Angeles, Los Angeles, CA 90095, USA ${ }^{8}$ Department of Biological Chemistry, David Geffen School of Medicine, University of California Los Angeles, Los Angeles, CA 90095, USA and ${ }^{9}$ The VA Greater Los Angeles Healthcare System, Los Angeles, CA 90073, USA
}

Correspondence: S Memarzadeh (smemarzadeh@mednet.ucla.edu)

These authors contributed equally: V. La, R. Fujikawa, D. M. Janzen.

Published online: 01 August 2018 